\title{
The Morphogenesis of the Sexually Indifferent Gonads in the Rabbit
}

\author{
Reda Mohamed ${ }^{1,2, *}$, Zein Adam², Mohammed Gad², Khalid Mazher ${ }^{3}$ \\ ${ }^{1}$ Department of Basic Veterinary Sciences, School of Veterinary Medicine, Faculty of Medical Sciences, The University of the West Indies, \\ St. Augustine, Republic of Trinidad and Tobago \\ ${ }^{2}$ Department of Anatomy and Embryology, Faculty of Veterinary Medicine, Beni Suef University, Beni Suef, Egypt \\ ${ }^{3}$ Department of Cytology and Histology, Faculty of Veterinary Medicine, Beni Suef University, Beni Suef, Egypt
}

\section{Email address:}

kkidareda@gmail.com (R. Mohamed)

${ }^{*}$ Corresponding author

\section{To cite this article:}

Reda Mohamed, Zein Adam, Mohammed Gad, Khalid Mazher. The Morphogenesis of the Sexually Indifferent Gonads in the Rabbit. International Journal of Clinical and Developmental Anatomy. Vol. 3, No. 6, 2017, pp. 57-63. doi: 10.11648/j.ijcda.20170306.12

Received: December 6, 2017; Accepted: December 20, 2017; Published: January 8, 2018

\begin{abstract}
The present study aimed to point out the prenatal developmental stages of the indifferent gonads in rabbit. About 50 embryos and fetuses aged 11 to 18 days postcoitum were used in this study. The embryos of 9 days-old up to 13 days-old fetuses were fixed firstly within the uterus by using modified Davidson's fixative and then were transferred with the caudal halves of the fetuses aged from 14 to 18 days postconception into $10 \%$ Neutral buffered formalin for 24 to 48 hours. The specimens were prepared using routine histological work. The morphogenesis of the sexually indifferent gonad of the rabbit was studied by high-resolution light microscopy. The results showed that the gonadal ridges were detected at the $12^{\text {th }}$ day postconception as a cellular thickening covered by coelomic epithelium on either sides of the dorsal mesentery and attached to the developing pronephros. As the development progressed the gonadal ridge increased in size and cellular constituents and became housing blood vessels and germ cells. The current work concluded that the gonads of the rabbit remained indifferent and neither testis nor ovary was observed until the $17^{\text {th }}$ day postconception.
\end{abstract}

Keywords: Parental, Development, Indifferent Gonads, Fetus, Rabbit

\section{Introduction}

The rabbit is considered as a good source for meat and fur production. The rabbit's meat shows high values for human consumption, it has a higher percentage of protein, which is easily digestible. Rabbit is valued as a popular live laboratory animals used in laboratory researchers as its ability to adapt itself to the changes in environment and it gives offspring monthly. In rabbit, the copulation is necessary to initiate ovulation which occurs approximately 10 hours after copulation, so that allow accurate pregnancy timing [1]. The present study aimed to point out the origin of rabbit gonads and clarify the prenatal developmental stages of the indifferent gonads in rabbit.

\section{Material and Methods}

\subsection{Animal Preparation}

In the present study, a total number of 50 rabbit embryos and fetuses were used. Baladi rabbits were obtained from local breeders. Adult females were housed individually under a good managemental condition for two weeks. The female rabbits were mated with a healthy fertile buck of the same breed. The female was left with male for two hours periods in the late afternoon as a day that was arbitrarily designated as day 0 pregnancy for the purpose of timing the pregnancy [2]. Since the ovulation in rabbit is induced only after coital stimulation and occurred about 10 to 12 hours [3]. About 12 hours were discarded from the calculation to arrive at the true age. The pregnant female rabbits were verified and they were slaughtered daily from $9^{\text {th }}$ day postconception until $18^{\text {th }}$ day. 
The embryos and fetuses were taken and crown vertebral rump length (C. V. R. L) was measured from start point of the forehead up to the base of the tail along the dorsum of the embryo or fetus. The embryos of $9^{\text {th }}$ day-old up to $13^{\text {th }}$ dayold fetuses were fixed firstly within the uterus by using modified Davidson's fixative and then were transferred to one of the used fixatives. While the caudal halves of the fetuses aged from 14 to 18 days postconception were transferred into $10 \%$ Neutral buffered formalin for 24 to 48 hours, Bouin's fluid for 12 to 24 hours or Modified Davidson's solution for 12 hours [4].

\subsection{Tissue Preparation and Histological Examination}

After fixation, the specimens were dehydrated in ascending grades of ethanol concentrations, cleared in xylene and embedded in paraffin wax or paraplast. Serial and step serial sections of 4-6 um thick were obtained, then dewaxed in xylene, hydrated in series of descending ethanol and stained by different stains according to $[5,6]$ including Harris Haematoxylin and eosin stain (H\&E) for general histological examination and Periodic acid Schiff (PAS) for detection of neutral mucopolysaccharides. Stained sections were examined by light microscope and photographed by Leica microscope system with digital camera at different powers.

\section{Results}

The initial step in the development of the rabbit gonad was the formation of the gonadal ridge which appeared at $12^{\text {th }}$ day postconception. It appeared as a cellular thickening covered by coelomic epithelium on either sides of the dorsal mesentery and attached to the developing pronephros (Figure 1). The core of the gonadal ridge was formed of clusters of undifferentiated mesenchymal cells with their slightly basophilic cytoplasm and centrally located oval to spherical nuclei. Such developing gonadal core was permeated by many blood capillaries devoid of blood cellular elements. The covering gonadal or coelomic epithelium was formed of one to two layers of columnar cells which were in direct contract with underlying mesenchymal cells due to the absence of basal lamina (Figure 2).

In $13^{\text {th }}$ day-old rabbit fetus, the gonadal primordia became larger in size and bulged into the coelomic cavity. The blood capillaries permeating the developing primordia contained nucleated red blood cells similar to those appeared in the developing mesonephros and abdominal aorta (Figure 3). The coelomic epithelium appeared to be formed of a single layer of columnar cells showing mitotic activity and had a great resemblance to the underlying mesenchymal cells in the gonadal core and mesonephros mesenchyme (Figure 4). During the same period of development, the coelomic epithelium reacted moderately to the PAS technique. The reaction appeared in the apices of these cells and partially in the interrupted basal lamina which started to appear at the $13^{\text {th }}$ day of development (Figure 5).

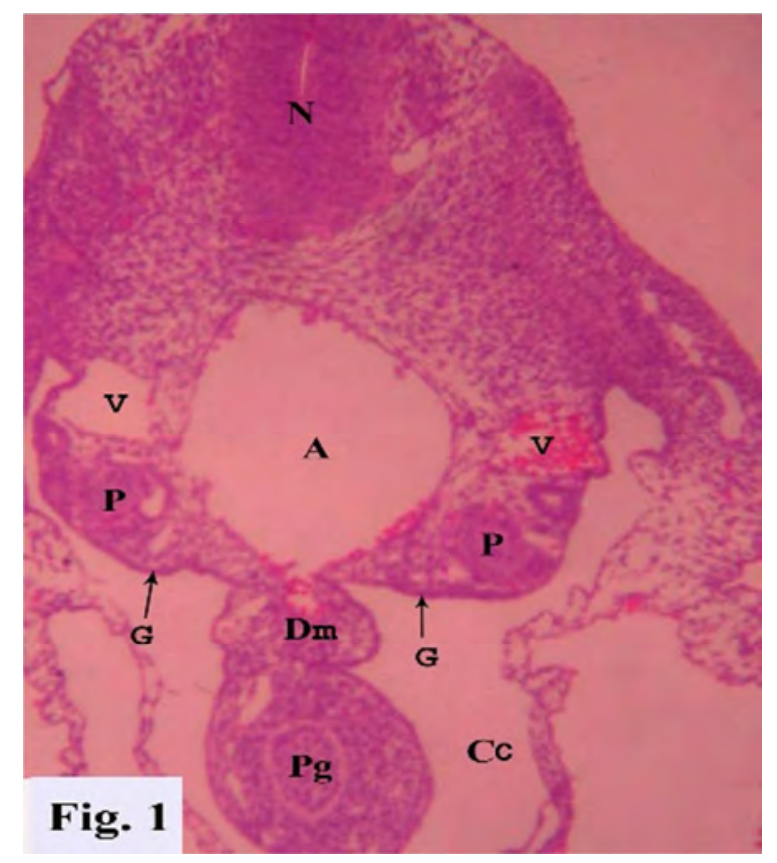

Figure 1. A cross section through 12th day-old rabbit fetus showing first appearance of gonadal ridge on either sides of the dorsal mesentery and attached to the pronephros H\&E stain, X100. A-Fetal aorta; Cc-Coelomic cavity; Dm-Dorsal mesentery; G-Gonadal ridge; P-Pronephros. -Primitive gut; N-Notochord; V-Cardinal vein.

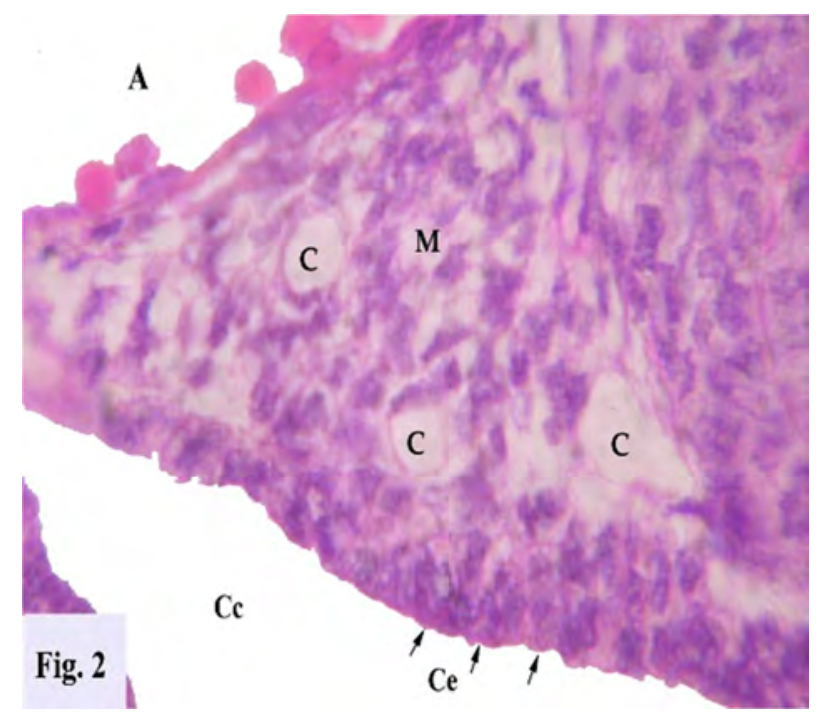

Figure 2. A higher magnification of gonadal primordia of 12th day-old rabbit fetus showing coelomic epithelium formed of one or two layers of columnar cells while the underlying core formed of mesenchymal cells permeated by blood capillaries. H\&E X, 1000. A - Fetal aorta; C - Blood capillaries; Cc - Coelomic cavity; Ce - Coelomic epithelium; $M$ Mesenchymal cells.

As development enhanced, from $14^{\text {th }}$ up to $17^{\text {th }}$ day of fetal rabbit life, the developing gonadal ridge increased in size, more bulged in the coelomic cavity and was seen attached to the mesonephros by mesogonadium which had a vascular net. The gonadal primordia showed a progressive increase in its cellular content which tended to form regular groups of cells known as the gonadal cells which formed gonadal cords. The clusters of cells appeared to down growth from 
the coelomic epithelium to the underlying developing core and from the mesenchymal cells of both the gonadal core and the mesonephros (Figure 6). During this period, the developing gonad was invaded by many germ cells which were endodermal in origin. The latter appeared spherical with rounded central euchromatic nuclei and slightly basophilic cytoplasm. Also, numerous mitotic figures at different phases could be noticed between the developing gonadal cells. The latter appeared slightly differentiated containing spherical centrally located nuclei in a slightly basophilic more differentiated cytoplasm. The epithelial cells of the coelomic epithelium showed focal areas of stratification. (Figure 7). Many cells of the developing gonadal core at this stage reacted moderately to PAS technique and the basal lamina still interrupted (Figure 8).

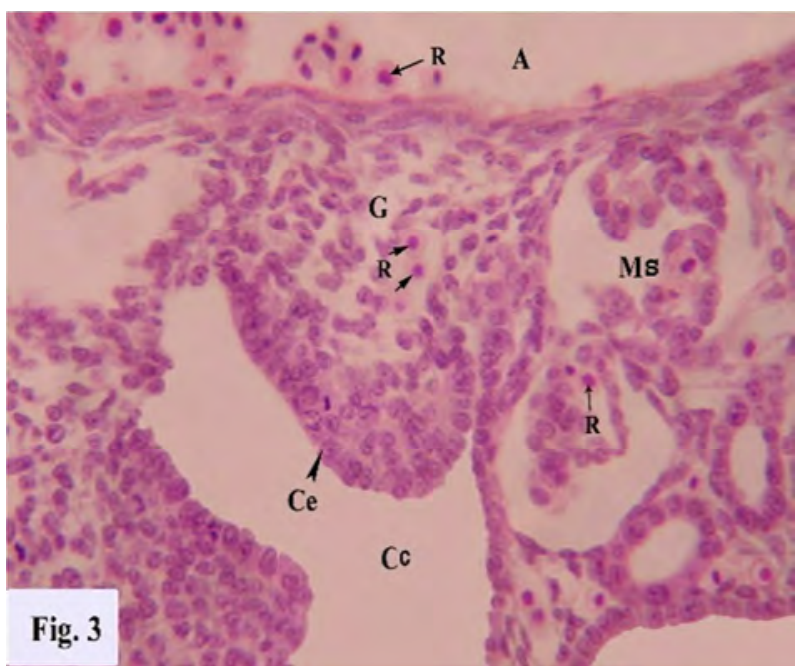

Figure 3. A photograph of $13^{\text {th }}$ day-old rabbit fetus showing gonadal primordia became lager, bulged in the coelomic cavity and housing nucleated RBCS. H\&E stain, X400. A -Fetal aorta, Cc -Coelomic cavity; Ce -Coelomic epithelium; $G$-Gonadal primordia; $M s$-Mesonephros; $R$ RBCS.

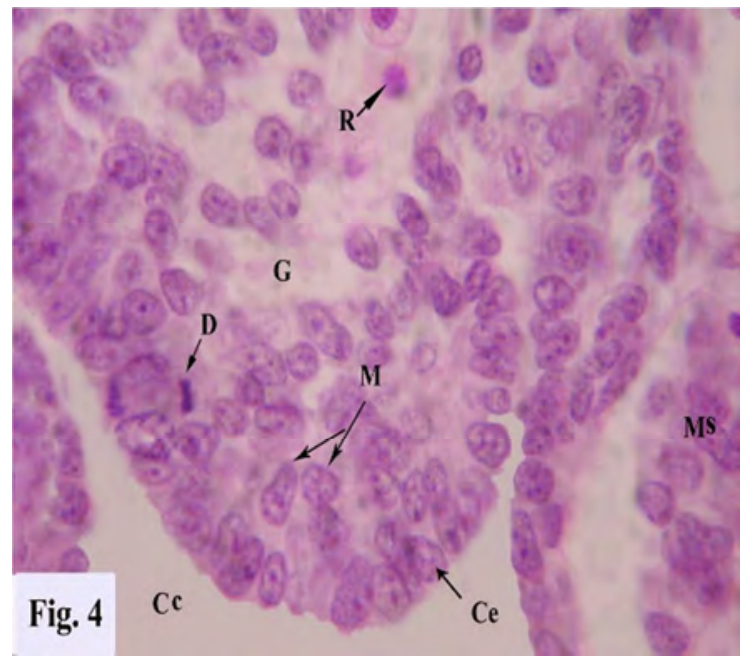

Figure 4. A higher magnification of gonadal primordia of $13^{\text {th }}$ day-old rabbit fetus showing coelomic epithelium became single layer of columnar cells showing mitotic activity. H\&E stain, X1000. Cc-Coelomic cavity; Ce - Coelomic epithelium; D - Mitotic division; G- Gonadal primordia; $M$ Mesenchymal cells; Ms-Mesonephros; R- RBCS.

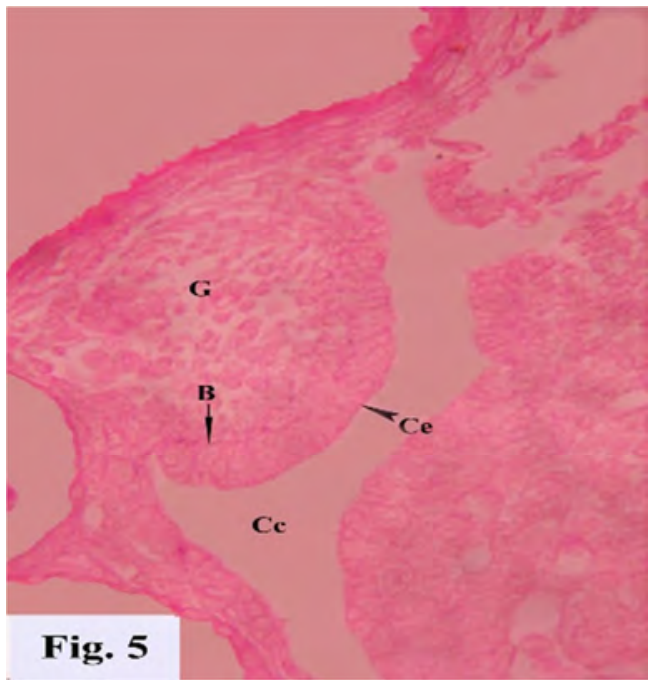

Figure 5. A photomicrograph of $13^{\text {th }}$ day-old rabbit fetus showing a moderate PAS reaction in the apices and basement membrane of coelomic epithelium of gonadal primordia. PAS reaction, X400. B-Basal lamina; CcCoelomic cavity; $\mathrm{Ce}$-Coelomic epithelium; $G$ - Gonadal primordia.

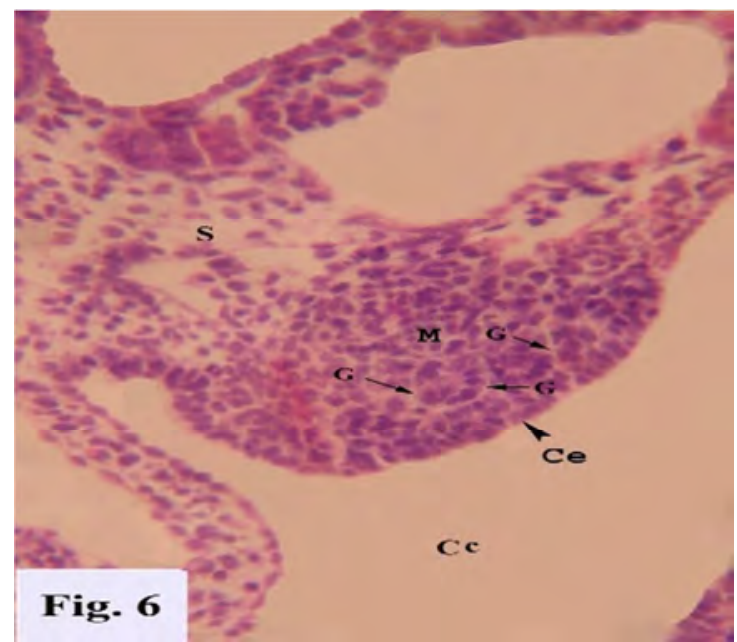

Figure 6. A cross section through the developing gonadal ridge of $14^{\text {th }}$ day old rabbit fetus showing progressive increase in number of gonadal cells which forms the gonadal cords. Note the coelomic epithelium still showed downgrowth to the underlying mesenchyme. H\&E stain X, 400. CcCoelomic cavity; $\mathrm{Ce}$ - Coelomic epithelium; $G$ - Gonadal cell cords; $M-$ Mesenchymal cells; $S$-Mesogonadium.

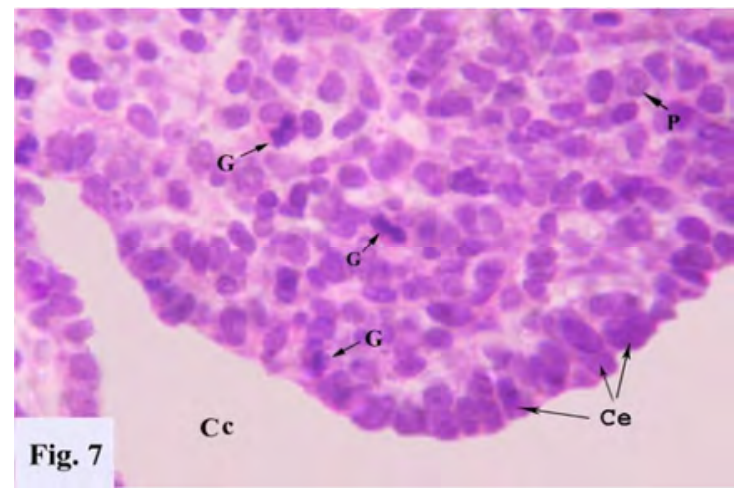

Figure 7. A higher magnification of gonadal primordia of $14^{\text {th }}$ day-old rabbit fetus invading by many germ cells. Note, mitotic figures between the gonadal cells. H\&E stain, X1000. Cc - Coelomic cavity; Ce - Coelomic epithelium (Stratification); $G$ - Gonadal cells; P-Primordial germ cell. 


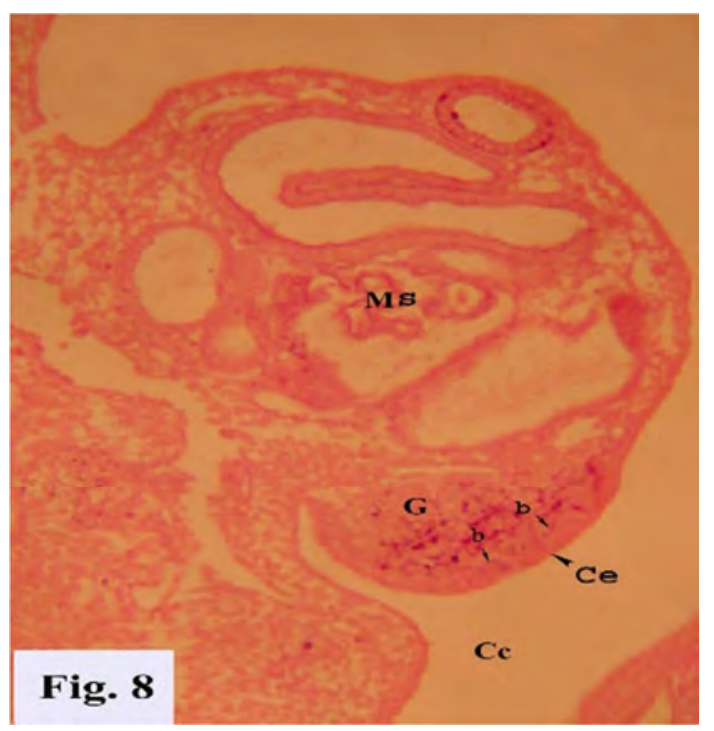

Figure 8. A photomicrograph of $17^{\text {th }}$ day-old rabbit fetus showing moderate $P A S$ reaction in the gonadal cells. PAS technique, X400. b-Basal lamina; $C c$ - Coelomic cavity; $C e-$ Coelomic epithelium; Ms - Mesonephros; $G-$ Gonad primordia.

\section{Discussion}

The current investigation in rabbit fetus revealed that the gonadal ridge appeared at $12^{\text {th }}$ day postconception which is simulated that reported in mouse [7] and in rat [8]. While, it appears at $10^{\text {th }}$ day postcoitum in rabbit [9]. However, the gonadal ridge appears at $11^{\text {th }}$ day postcoitum in rabbit [10, $11]$, in mouse [12], in rat $[13,14]$ and in golden hamster [15]. On the other hand, the gonadal ridge appears at $13^{\text {th }}$ day postcoitum in rabbit $[2,16]$ and in rat $[17,18]$. The gonadal ridge appears at $22^{\text {nd }}$ day postcoitum in ferret [19]. The gonadal ridge appears at $21^{\text {st }}$ day postcoitum in guinea pig [19]. The gonadal ridge appears at $24^{\text {th }}$ day postcoitum in sheep [20].

The current study showed that the gonadal ridge appears as bilateral cellular thickening covered by coelomic epithelium on either sides of the dorsal mesentery and attached to the developing pronephros. These findings are parallel with that described in rabbit [10], in rat [17], in guinea pig [21], in goat [22], in dog [23]. While, the gonadal ridge appears as bilateral thickening ventral to the mesonephros in and in rat [8], rabbit [11] and in mouse [24]. On the other hand, the gonadal ridge appears as a distinct edge formed by the thickening of the coelomic epithelium at the inner surface of the mesonephros in rabbit [2,16], in rat [13] and in guinea pig [21]. The gonadal ridge is situated ventromedially to the mesonephros in mouse [25]. The site where the gonad is to develop appears as a narrow strip of mesenchyme between the ventral termination of the mesonephric tubules and the coelomic epithelium in mouse [26]. While, in the same animal mentioned that the gonadal ridge is located between the coelomic epithelium and the mesonephric tubules [7]. However, the gonadal ridge develops as a narrow band of tissue close to kidney in mouse [27]. The gonadal ridge appears as a thickening of the coelomic epithelium on the ventrolateral aspect of the mesonephros in mouse, rat and sheep [28] and in rat [29]. The gonadal ridge appears as a bulging into the coelomic cavity on the medial side of the mesonephros in golden hamster [30].

In the present work, the core of the gonadal primordia in $12^{\text {th }}$ day-old rabbit fetus was formed of clusters of undifferentiated mesenchymal cells, permeated by many blood capillaries devoid of blood cellular elements and covered by coelomic epithelium, simulated that in $14^{\text {th }}$ dayold rabbit fetus [11], in mouse and rat [31], in rat [14], in guinea pig [19] and in dog [23]. Jimenez (2009) in mouse reported that the gonadal blastema including the epithelial, mesenchymal and endothelial cells as well as primordial germ cells in mouse [25].

The current study achieved that the covering coelomic epithelium of the gonadal ridge was formed of one to two layers of columnar cells at $12^{\text {th }}$ day postconception and became one layer of columnar cells at $13^{\text {th }}$ day postconception, similar observation was in guinea pig [21]. While, the covering epithelium of the gonadal anlage formed of one or two cellular layers of cuboidal or flattened germinal epithelium in rabbit [10], in mouse [32] and in goat [22]. On the other hand, one layer of cuboidal cells of the germinal epithelium covers the gonad in rabbit [11].

The present work showed a direct contact between coelomic epithelium and underlying mesenchymal cells due to the absence of basal lamina up to $12^{\text {th }}$ day postconception. While, the basal lamina is absent up to 13 th in rabbit $[2,10$, 16] and 11th day postcoitum in mouse [33].

The absence of basal lamina at as well as the great resemblance between the surface epithelial cells, mesenchymal cells of the gonadal core and mesonephros mesenchyme forced us to confirm that the surface epithelium and mesonephros mesenchyme played a pronounced role in the formation of gonadal core. While, the mesonephros mesenchyme give gonadal mesenchyme in rabbit $[10,16]$, in rabbit and rat [29], in goat [22], in dog [23] and in domestic animals [34]. The mesonephros gives epithelial cells, which contribute to the thickening of the gonadal ridge in rabbit [2]. The coelomic epithelium gives the mesenchymal cells of the developing gonad in rat [13], in guinea pig [21] and in mouse [35]. The coelomic epithelium is not contributed to the developing gonad in golden hamster [30].

The current study showed that the undifferentiated mesenchymal cells appeared with their slightly basophilic cytoplasm and centrally located oval to spherical nuclei. While, the undifferentiated mesenchymal cells are elongated in shape with fine acidophilic cytoplasmic processes and darkly stained elongated or rod-shaped nuclei in rabbit [10]. The somatic cells of the gonadal primordia exhibit epithelioid characters and have large slightly indented nuclei with finely dispersed chromatin in mouse [26].

The current study showed that the coelomic epithelium showed mitotic activity in $13^{\text {th }}$ day-old rabbit fetus. The finding was parallel with that described in rabbit [2]. While, the mitotic activity of the coelomic epithelium occurs in $11^{\text {th }}$ or $12^{\text {th }}$ day-old rabbit fetus $[10,11]$ respectively and in in 
$12.5^{\text {th }}$ day-old rat fetus [38].

The current work revealed that there was an interrupted basal lamina appeared at $13^{\text {th }}$ day postconception which partially separated the underlying mesenchymal cells from the coelomic epithelium. Such results confirmed in $12.5^{\text {th }}$ to $13.5^{\text {th }}$ day-old rabbit fetus [29], in 12 days-old mouse fetus [33] and in $13^{\text {th }}$ day-old rat embryo [38].

The recent study asserted that the gonadal primordia of $13^{\text {th }}$ day-old rabbit fetus enlarged and protruded into the coelomic cavity. A result which was also recorded in rabbit [10]. While, the gonadal primordia protrude into the coelomic cavity at $12^{\text {th }}$ day of fetal rabbit life [11]. On the other hand, the gonadal primordia protrude at $14^{\text {th }}$ day postconception in rabbit $[2,16]$. The gonadal primordia protrude into the coelomic cavity at $11.5^{\text {th }}$ day postcoitum [24]. The gonadal primordia project into the coelomic cavity at $25^{\text {th }}$ day postcoitum in guinea pig [21].

The present investigation revealed that the primordial germ cells reached the gonadal primordia at $14^{\text {th }}$ day postconception resembling that described in rat [17]. While, the primordial germ cells reach gonadal ridges at $11^{\text {th }}$ day of fetal rabbit life [10]. The primordial germ cells reach the gonadal ridge at 12.5 th day postcoitum [36]. The primordial germ cells are present within the gonadal ridge at $17^{\text {th }}$ day postcoitum in guinea pig [21]. The primordial germ cells reach the gonadal ridge at $21^{\text {st }}$ day postcoitum in sheep [28].

The current study showed that the primordial germ cells appeared spherical with rounded central euchromatic nuclei and slightly basophilic cytoplasm. Similar result was recorded in rabbit [37], in mouse [32], in rat [38] and in guinea pig [21].

The recent study asserted that few primordial germ cells were present within the core of the developing gonad, simulated that recorded in rabbit [10], in rat [28], in ferret [18] and in goat [22].

The obtained results showed that the primordial germ cells arose from gut epithelium (endodermal in origin). A result which was also recorded in mouse [39] and in mammals [40]. The primordial germ cells arise from both, the gut epithelium (endodermal) and from the coelomic epithelium in guinea pig [21].

In the present work, the gonadal primordia were attached by mesogonadium to the mesonephros at $14^{\text {th }}$ day postconception and it had a vascular net, while, the mesogonadium appears at $11^{\text {th }}, 12^{\text {th }}$ or $13^{\text {th }}$ day of fetal rabbit life $[10,16,11]$ respectively.

The recent study asserted that the primitive gonadal cords were formed from the primitive gonadal cells of the gonadal core at $14^{\text {th }}$ day postconception. While, the primitive gonadal cords are formed from the primitive gonadal cells at 11th and 15 th days of fetal rabbit life $[10,11]$ respectively. On the other hand, the gonadal cords are formed from cords of epithelial cells from mesonephros which coalesce to form clusters which incorporate primordial germ cells in 13th dayold rat fetus [38] and in domestic animals [34].

The present work showed that the gonadal core became increased in size due to the continuous formation of the primitive gonadal cords through the mitotic activity of the gonadal mesenchyme, downgrowth of cells from coelomic epithelium and migratory cells from the mesonephros mesenchyme at $14^{\text {th }}$ to $17^{\text {th }}$ day postconception, a result which was also recorded in $13^{\text {th }}$ day-old rabbit and rat fetuses $[10,39]$ respectively, in goat [22] and in dog [23].

The obtained results showed that the gonadal cells appeared slightly differentiated containing spherical centrally located nuclei in a slightly basophilic more differentiated cytoplasm. A result which was also recorded in the same animal [10].

In the present work, the epithelial cells of the coelomic epithelium showed proliferation due to mitotic division resulted in focal areas of stratification in the coelomic epithelium in $14^{\text {th }}$ day-old rabbit fetus, simulated that reported in 13th day -old rabbit fetus $[2,10]$ and in $12.5^{\text {th }}$ day-old rat fetus [38].

The obtained results showed that the gonadal primordia contained coelomic epithelium, undifferentiated mesenchymal cells, gonadal cells and cords, primordial germ cells and apparent blood spaces in $14^{\text {th }}$ to $17^{\text {th }}$ day-old rabbit fetus. A result which was also recorded at $11^{\text {th }}$ day of fetal rabbit life [10] and in goat [22].

\section{Conclusion}

The initial step in the development of the rabbit gonad was the formation of the gonadal ridge which appeared at 12 days postconception as a cellular thickening covered by coelomic epithelium. In $13^{\text {th }}$ day-old rabbit fetus, the gonadal primordia became larger in size and bulged into the coelomic cavity. From $14^{\text {th }}$ up to $17^{\text {th }}$ day of fetal rabbit life, the gonadal primordia have the gonadal cells which formed gonadal cords and the developing gonad was invaded by many germ cells which were endodermal in origin.

\section{Acknowledgements}

The authors acknowledge the expert technical assistance of Anatomy and Histology Departments

\section{Conflict of Interest}

All the authors do not have any possible conflicts of interest.

\section{References}

[1] George, F. W. and J. D. Wilson (1979). The regulation of androgen and estrogen formation in fetal gonads. Annales de biologie animale, biochimie, biophysique, 19 (4B), 12971306.

[2] Diaz-Hernandez, V., A. Leon del Rio, M. Zamora, and H. Merchant- Larios (2008). Expression profiles of SRYand SOX9 in rabbit gonads: The classical model of mammalian sex differentiation. Sexual Development 2 (3), 152-166. 
[3] Hayashi, T., Y. Kageyama, K. Ischizaka, K. Kihara, and H. Oshima (2002). Involvement of apoptosis in the control of Sertoli cells and pre-meiotic germ cell numbers in the developing rabbit testis. Andrologia 34 (1), 34-40.

[4] Lihui, T. U., Y. Lili, and H. Zhang (2011). Morphology of rat testis preserved in three different fixatives J Huazhong Univ Sci Technol (Med Sci), 31 (2): 178-180.

[5] J. D. Bancroft and A. Stevens, "Theory and practice of histological techniques". 4th Ed., Churchill-Livingstone, Edinburgh, London, Melbourne, New York. 1996.

[6] J. D. Bancroft and A. Gamble, "Theory and practice of histological" techniques. 6th Ed., Churchill- Livingstone, Edinburgh, London, Melbourne, New York: 2008.

[7] Kanal. Y., M. Kurohmaru, Y. Hayashi, and T. Nishida, (1989). Formation of male and female sex cords in gonadal development of C57BL16 Mouse. The Japanese Journal of Veterinary Science 51 (1), 7-16.

[8] Frodjman, k., J. Paranko, I. Virtanen, and L. J. Pelliniemi (1992). Intermediate filaments and epithelial differentiation of male rat embryonic gonads. Differentiation 50 (2), 113-123.

[9] Chretien, F. R., (1968). Annales d'embryologie et de morphogenes. "Journal of embryology and experimental morphology 1,361-372.

[10] El-Oksha, S. M., (1993). Developmental studies on the testis of rabbit. MSc Thesis, Faculty of Veterinary Medicine, Moshtohor, Zagazig University (Benha), Egypt.

[11] Konsowa, M. M., (1997). The development of the male genitalia of the rabbit with reference to its vasculature. $\mathrm{PhD}$ Thesis, Faculty of Veterinary Medicine, Zagazig University, Egypt.

[12] Tohonen, V., J. Frygelius, M. Mohammadieh, U. Kvist, L. J. Pelliniemi, K. O'Brien, K. Nordqvist, and A. Wedell (2005). Normal sexual development and fertility in testatin knockout mice. Molecular and Cellular Biology 25 (12), 4892-4902.

[13] Hargitt, G. T., (1925). The formation of the sex glands and germ cells of mammals. I. The origin of the germ cells in the albino rat. Journal Morphology and Physiology 40, 517-557.

[14] Torrey, T. W., (1945). The development of the urogenital system of the albino rat. American Journal of Anatomy 76, 375-397.

[15] Challoner, S., (1974). Studies of oogenesis and follicular development in the golden hamster I- A quantitative study of meiotic prophase in vivo. Journal of Anatomy 117 (2), 373-383.

[16] Wartenberg, H., B. Hilscher, and W. Hilscher (1998). Germ cell kinetics during early ovarian differentiation: An analysis of the oogonial cell cycle and the subsequent changes in oocyte development during the onset of meiosis in rat. Microscopy Research and Technique 40, 377-397.

[17] Eddy, E. M., (1974): Fine structural observations on the form and distribution of the Nuage in germ cells of the rat Anat. Rec 178 (4), 731-757.

[18] Deanesly, R., (1977). Testis differentiation in the fetal and postnatal ferret. Journal of Anatomy 23 (3), 589-599.

[19] Black, V. H. and A. K. Christensen. (1969): Differentiation of interstitial cells and Sertoli cells in foetal guinea pig testis. American Journal of anatomy 124 (2), 211-238.
[20] Juengel, J. L., H. R. Sawyer, P. R. Smith, L. D. Qurike, D. A. Heath, Stan Lun, St. J. Wakefield, and K. P. McNatty (2002). Origins of follicular cells and ontogeny of steroidogenesis in ovine fetal ovaries. Molecular and Cellular Endocrinology 191 (1), 1-10.

[21] Bookhout, C. G., (1936). The germ cell cycle in the guinea pig. I- The embryonic development of the testis. Cell Tissue Research 25 (5), 728-748.

[22] Mazher, K. M., (1997). Histological studies of the testis of the goat fetuses. MVSc Faculty of Veterinary Medicine, Cairo University (Beni Suef Branch), Egypt.

[23] H. T. Gier, and G. B. Marion, "Development of the mammalian testis". In: the testis. Eds. Johnson, A. D., Gomes, W. R. and Vandmark, N. L. Vol. I., ch. 1: 1-45. Accad. Press., New York, London. 1970.

[24] Merchant-Larios, H. and V. Diaz-Hernandez (2011). Topics in animal and plant development: from cell differentiation to morphogenesis, 4- Gonadal development75-91.

[25] Jimenez, R., (2009). Ovarian organogenesis in mammals: Mice cannot tell us everything. Sexual Development 3 (6), 291-301.

[26] Upadhyay, S., J. M. Luciani, and L. Zamboni (1979). The role of the mesonephros in the development of indifferent gonads and ovaries of the mouse. Annales De Biologie Animale, Biochimie, Biophysique 19 (4 B), 1179-1196.

[27] Merchant-Larios, H. and N. Moreno-Mendoza (1998). Mesonephric stromal cell differentiate into Leydig cells in the mouse fetal testis. Experimental Cell Research 244 (1), 230238 .

[28] Celine, J., Guigon, and S. Magre (2006). Contribution of germ cells to the differentiation and maturation of the ovary: Insights from models of germ cells depletion. Biology of Reproduction 74 (3), 450-458.

[29] Sarker, S., A. K. Dubey, and P. N. Shah (1978). Early changes in differentiating gonads of rat and rabbit. Indian Journal of Experimental Biology 16 (1), 13-17.

[30] Mackay, S., A. A. Bashir, and D. H. Barnie (1989). Primordial germ cells and gonadal development in golden hamster. Journal of Anatomy 164, 155-163.

[31] Pelliniemi, L. J, K. Frojdman, and Sundstrom (1998). Cellular and molecular changes during sex differentiation of mammalian embryonic gonads. Journal of Experimental Zoology 281 (5), 482-493.

[32] Eguchi, Y. and Y. I. Hashimoto (1961). Histological development of the testis of the mouse during embryonic stages. Bull Univ Osaka Pref Ser B 40 11, 77-83.

[33] Smith, C. and S. Mackay (1991). Morphological development and fate of the mouse. Journal of Anatomy 174, 171-84.

[34] D. M. Noden, and A. Delahunta, "The embryology of domestic animals". Developmental mechanisms and malformations. Williams and Wilkins. Baltimore, London. 1985.

[35] Heikkila, M., (2002). Development of the adreno-genital system. Female sex determination, ovarian and adrenal gland ontogeny regulated by Wnt-4 in mice. Faculty of Biochemistry and Molecular Medicine, Oulu University, Finland. 
[36] Jelici, M. D., S. Dolci, and M. Pesce (1992). Cellular and molecular aspects of mouse primordial germ cells migration and proliferation in culture. The International Journal of Developmental Biology 36 (2), 205-213.

[37] Allen, B. M., (1904). The embryonic development of the ovary and testis of the mammals. The American Journal of Anatomy 3 (2), 89-154.

[38] Satoh, M., (1985): The histogenesis of the gonad in rat embryos. Journal of Anatomy 143, 17-37.
[39] Kocer, A., J. Reichmann, D. Best, and L. R. Adams (2009). Germ cell sex determination in mammals Molecular human reproduction, 15 (4), 205-213.

[40] Peters, H., (1970). Migration of gonocytes into the mammalian gonad and their differentiation. Philosophical Transactions of the Royal Society B (Biological Sciences) 259 (828), 91-101. 